УДК 81'32

https://doi.org/10.31548/philolog2020.02.110

\title{
COMMUNICATION STRATEGIES IN INSTRUCTION / ACQUISITION OF LANGUAGES FOR SPECIFIC PURPOSES
}

\author{
O. I. CHAIKA, PhD in Philology, Associate Professor, \\ National University of Life and Environmental Sciences of Ukraine \\ E-mail: oxana.chaika@yahoo.es \\ https://orcid.org/0000-0002-4317-9456
}

\begin{abstract}
The present paper looks at a set of communication strategies employed in teaching and learning a language for specific purposes taken that such language for specific purposes is a language other than a native language to the speaker. English examples drawn from a variety of business and cultural backgrounds, i.e. English for Business, Law, Finance and Audit, Change Management, Leadership, etc. illustrate variability in communication strategies employed by the speaker but as opposed to a circumstance of foreign language instruction and language acquisition demonstrate the critical importance of linguistic competence as well. The paper aims to (i) provide definitions of the communicative strategy as followed in literature, (ii) discuss taxonomies of communication strategies that speakers use to present their thoughts and ideas in English for specific purpose in a(n) [non-native] English-speaking environment, and (iii) stretch that further to professional communication models in a foreign language climate when acquiring new linguistic and strategic skills and competences. Thus, the work includes a linguistic / product-oriented typology of communication strategies (proposed by Dornyei 1995) since it incorporates most commonly shared communication strategies found in Varadi's, Tarone's, Faerch and Kasper's, and Bialostok's typologes: (a) avoidance strategies, or reduction CS; (b) compensatory, achievement, strategies; and (c) time-gaining communication strategies.
\end{abstract}

Keywords: Communication strategy, language acquisition, language instruction, language for specific purposes (LSP), circumlocution, semantic avoidance, word coinage, language switch, nonverbal strategies.

Introduction. It is via communication that people send and receive messages - either in their mother tongue (source language, L1), or a foreign language (target language, L2). Further, the question arises how effectively people may communicate to encode / decode and negotiate the meaning. What happens next when the proper word in a target language is missing in the speaker's vocabulary or the grammar pattern needs remedy. On top of these few, it is even more challenging to follow one of the interesting phenomena, which takes place in a foreign language environment, e.g. English-speaking environment, when language for specific purposes steps in, on the one hand, and the solution found by the speaker, on the other. Here are some instances:

(i) A Ukrainian lawyer is observed as she explains a court ruling on seizure of the Firm's funds to an American partner. In English, her second language (L2), she says, "The court has ruled, uh, sorry l'm not sure it's the right word, uh, to arrest the funds", or

(ii) A native speaker of Portuguese is observed as he describes in English (his L2) a language instructor at the son's school, by saying, 'Ms ... is [an] English Professor', as in Portuguese it sounds, 'Senhora ... é Professora de inglês', or

(iii) A Brazilian businessperson speaks to an Englishman and wants to inform him that $\mathrm{s}$ /he has never been to England before, 'I don't know England', as in Brazil they say, 'Não conheço Inglaterra'.

Such phenomena are frequent in intercultural communication and are referred to as communication strategies following a number of recent studies (Tarone 1981, Houston 2006, Zhang 2007) [12; 13; 18]. At the same time, we agree with Tarone (1981)

(C) O. I. Chaika

«International journal of philology» | «Міжнародний філологічний часопис» Vol. 11, № 2, 2020 
the term "communication strategy" should not be confused with the other terms, which may be seen used interchangeably, i.e. learning strategy, production strategy, and perception strategy $[12,285]$. Thus, the objective of the paper is to differentiate communication strategies employed for foreign language acquisition / instruction among others and discuss relevant instruction specifics of communication strategies for teaching languages for specific purposes (LSP) taken that such LSP are languages other than a native language to the speaker. To achieve the goals, certain tasks are set:

(i) To define communication strategies in language instruction / acquisition following a number of definitions documented by scholars and researchers in their recent works,

(ii) To examine taxonomies of communication strategies, to be accompanied with English examples, and

(iii)To look at the results that may lead to success or failure in communication especially when L2 acquisition / instruction moves along with LSP.

Theoretical background and literature review, and the descriptive method may well contribute to value of the findings.

I. Communication Strategy, Definitions and Literature Review. Communication has always played a crucial role to achieve set goals in life and business, and it comes as no surprise why this research topic would appeal to many. To begin with, we will look here at some concepts and studies connected with communication strategies in terms of the definition and give a general description of such. Further, it will be discussed what classification of communication strategies (CS) may apply along with relevant taxonomies, focusing on different approaches, perspectives and expected outcome. Thus, linguists generally agree that CS aims to solve communication problems that may arise in the course of interaction and negotiation of a meaning. Next, the approach to deal with research may vary. Tarone (2018) in Interlanguage underlines that "strategies of communication are used by the learner to get meaning across when the interlanguage system does not yet provide the requisite forms to do so in a native-like way" as the author explores CS from the interactional point of view [12]. Faerch and Kasper (1984) focus on negotiation of meaning as it "is central to interactional strategies" [10] perceiving CS from the psychological standing as potential conscious plans by an individual to reach a communicative goal when solving a linguistic problem. Brown (1994, p. 118, cited from Griffiths 2004) speaks that "a learner generally applies the same fundamental strategies (such as rule transference) used in learning a language to communicating in that language, there are other communication strategies such as avoidance or message abandonment which do not result in learning" [11, 3-4], which fits in Tarone's (2018) understanding that "in the attempt to communicate meaning ... when the IL does not contain the exact lexical item needed, learners can use a variety of strategies of communication" [12, 2018].

To mention it large, reads of Váradi (1980), Corder (1978), Tarone (1981) lead to the focus of different forms of linguistic utterance that CS may produce while Faerch and Kasper (1980, 1983), Bialystok (1990), Poulisse (1993) refer to attempts of description and classification of mental processes underlying linguistic utterances, which altogether results in psycholinguistic taxonomies. We follow the research carried out and grounded by Ana María Fernández Dobao from Universidad de Santiago de Compostela, in which a number of factors may influence the choice of communicative strategies while taking into account learners' personality (Haastrup and Phillipson 1983), L1 background (Kellerman 1984), proficiency level (Hyde 1982; Paribakht 1985; Poulisse, Bongaerts and Kellerman 1990), or task demands (Poulisse, Bongaerts and Kellerman 1990) [6, 3]. Thus, Poulisse (1989) defines CS as strategies that are used by the speaker to solve communication problems caused by lack of appropriate forms (cognitive or lexical), which may be compensated either by going to the conceptual stage or by trying out alternative linguistic formulations [14]. Corder (1978) and Stern (1983) see CS as techniques: (i) ones that aim to cope with difficulties that arise

(c) O. I. Chaika

«International journal of philology» | «Міжнародний філологічний часопис» Vol. 11, № 2, 2020 
in communication where a speaker's level of linguistic competence (L2) is imperfect [16], (ii) such that are systematic and employed by a speaker to express their ideas when relevant difficulties occur [5].

As demonstrated above, there are differences in definitions of CS and for the purpose of the paper, we find it reasonable to further focus on the analysis of recent studies of CS and definition of the criteria for CS by Tarone (1981). Among the key criteria to us are: (i) the speaker wishes to communicate meaning to a listener; (ii) the speaker believes "the linguistic or sociolinguistic structure desired to communicate meaning $X$ is unavailable, or is not shared with the listener"; (iii) the speaker chooses either not attempt to communicate meaning $X$ by avoiding it, or attempts some other means to communicate meaning $X$. Next, the speaker may stop trying when such speaker seems to see that there is that shared meaning $[13,288]$.

Such criteria applicable to the definition of CS help us better understand a variety in typologies and taxonomies of CS in instruction and acquisition of languages for specific purposes commonly deliverable as Ukrainian for Business and Law, German for Car Manufacturing, French for Wines and Cuisine, English for Audit and Accounting, etc. Chaika (2018) states that "with each case specified, we may see that the content and core of the language instruction get narrowed to a specific context" $[4,53]$.

II. Taxonomies of Communication Strategies in Instruction / Acquisition of Languages for Specific Purposes. Communication strategies may vary in application by the speaker. For instance, in Chaika (2020) "Communication strategies forge and help maintain connections, communication strategies when properly applied help build up international teams and develop cross-border business effectively, communication strategies stand at attention to translate the message smoothly in order to reach the desired communicative goal" [1]. However, analysing a number of prominent works on CS and foreign language instruction / acquisition two main approaches stand out. One of them rests on the linguistic basis as it is product- oriented rather than process-oriented and the other is with the cognitive, or psychological, basis.

We will be looking at a linguistic / productoriented typology of CS (proposed by Dornyei 1995) since it incorporates most commonly shared CS found in Varadi's, Tarone's, Faerch and Kasper's, and Bialostok's typologies. The mentioned typology includes three CS types:

(a) Avoidance strategies, or reduction CS - the speaker applies the strategy to alter, or reduce, or abandon the message;

(b) Compensatory, achievement, CS the speaker looks for alternative plans and decides on compensating for lack of linguistic competence with word coinage, circumlocution, etc. in order to achieve the communication goal;

(c) time-gaining CS - the speaker uses filling words to gain the time to think by stretching the message with parentheses, introductory phrases, interjections, etc. This type of CS differs from the two above as it aims to keep communicating and have the communication channel open as opposed to the former that aim to compensate for linguistic deficiency.

The proposed typology also includes Tarone's (1981) five types of CS: (i) paraphrase, (ii) borrowing, (iii) appeal for assistance, (iv) mime, and (v) avoidance [13].

Type l: Avoidance / reduction communication strategies in instruction / acquisition of languages for specific purposes

- Message abandonment - the speaker leaves a message incomplete from a lexical or grammatical viewpoint, for example: EN Each Firm will conduct its own affairs independently of the other Firms and without control or direction from the National Association or ...from National Association [its Board of Representatives].

- Topic avoidance - the speaker avoids topics and/or [professional] subject areas, which may result in linguistic difficulties, e.g. EN Firms do not create relationship of partnership or (they do not create relationship) of principal and agent or of joint venture between such Firms or between the

(C) O. I. Chaika

«International journal of philology» | «Міжнародний філологічний часопис» Vol. 11, № 2, 2020 
Directors / Partners of any Firm and the Directors / Partners of the other Firms. [Save as provided in this agreement, no Firm as a result of being a party to this agreement shall be subject to any legal obligations or liabilities; or entitled to any rights in relation to the other Firms] - the latter part is missing as it turns out to the speaker next to impossible to discuss it in legal terms (i.e. English for Law as LSP). This leads to avoidance of the message by the speaker, s/he tries not to talk about legal concepts for which L2 / target language structure (terms) is not known.

Type II: Compensatory, or achievement, communication strategies in instruction / acquisition of languages for specific purposes

- Approximation - the speaker uses some alternates for terms that cause trouble in professional communication but tries to approximate the concept of the term in a target language / L2 as closely as possible: EN Each Firm will do its business [instead of will conduct its own affairs] independently of the other Firms and without control from the National Association or its Directors [instead of Board of Representatives]. The speaker uses a monomial (single term) Directors in English for Law (L2) and simplified structure do its business, which s/he knows are not correct and accurate in the professional domain of communication for lawyers, but which share enough concept in common with the desired business and law monomials (terms) to satisfy the speaker.

- Circumlocution - the speaker describes (exemplifies) the term, or thing, or action as finds it hard to provide an accurate term under a circumstance, for instance: EN Nominations for the ...., uh, main person, a kind of director of the National Association [Chairperson] and other ..., uh, sorry, I don't know what's the proper term, well, members to work with this Director of the Association [Representatives] shall be sent [submitted] in writing to the Executive Officer at least 10 Business Days prior to the Annual General Meeting. The speaker describes characteristics / elements of the term instead of using the proper $\mathrm{L} 2$ term or structure.

- Word / term coinage - the speaker makes up a non-existing term in another language (target language / L2) by applying linguistic means known to them (affixation, flexions, speech patterns, etc.): EN Each Firm will conduct its own affairs controllessly [independently] of the other Firms.

- Use of all-purpose words - the speaker extends terminological piece (term or structure, e.g. audit and accounting monomials and binomials) to a context which lacks such terms, for instance: EN (a) The assets and liabilities of the Brown Group must be disclosed separately on the what-do-youcall-it [face] of the statement of financial position. (b) Although the contract is currently on schedule, the Company is not entirely confident that the fines and that sort of things [penalty] can be avoided.

- Literal translation - the speaker literally translates terms, term clusters, term patterns, etc. (monomials and polynomials) in the professional domain from a source language (L1) to target language (L2), in particular: EN The counterparty does not hurry to sign the contract instead of The counterparty is reluctant to enter into agreement / make the contract. The speaker translates word for word from Ukrainian (L1) to English (L2).

- Foregnising (borrowing, according to Tarone) - the speaker uses professional terms from mother tongue and merely adjusts L2 pronunciation and/or morphological forms in another (target language / L2), for example: EN (a) They have set up an audit company [audit firm]; (b) The company's senior management will be hosting the conferencia [conference] on Corporate Law tomorrow.

- Language switch (Tarone 1981) - the speaker uses a native (source language / L1) term with $\mathrm{L} 1$ pronunciation, without bothering to translate it, e.g. EN The Firm's bank rakhunok [account] will be closed tomorrow.

- Appeal for assistance - the speaker may act in two ways asking for help, either directly (verbally, by asking specific questions)

(C) O. I. Chaika

«International journal of philology» | «Міжнародний філологічний часопис» Vol. 11, № 2, 2020 
or indirectly (non-verbally, by changing intonation - ascending tones, for example, eye contact, facial expressions, making longer pauses), for example:

EN Termination benefit may be defined as benefits pay able as a result of employment being terminated, either by the employer, or by the employee accepting ... what do you call it? [voluntary redundancy].

- Non-verbal means - the speaker uses mimes and gestures, facial expressions to communicate a message; at times sound imitation can become handy as well.

Type III: Time-gaining communication strategies in instruction / acquisition of languages for specific purposes

- Use of fillers and hesitation devices the speaker aims to gain the time to think and uses filling words to fill pauses in communication, for example: EN If the goods or services are received in exchange for ... well, let me see, equity (e.g. for share options), the entity ... as a matter of fact... recognises an increase in equity.

III. Communication strategies and challenges for instruction / acquisition of languages (English) for specific purposes

This paper presents applicable definitions of the communication strategies and overviews some general approaches to typologies and taxonomies of communication strategies in learning / teaching foreign languages and at the same time focuses on instruction / acquisition of languages for specific purposes. "With academic feed on FL instruction in terms of LSP and marketing of professional language products to meet the businesses " needs, it is now identification of potential objectives, evaluations and assessments of language structures, syntax, semantics and pragmatics in general and speech acts in discourse, in particular, that should be worth studying more where linguistic analyses are to be made and relevant findings exposed to contribute to the heritage of applied linguistics" [3, 121]. Communication as one of the potential objectives and negotiation of meaning / concepts are critical to bring in result and quality. Traditional analysis of errors in lexis and syntax takes good time for the speaker, communication strategies may be of help then. However, limited domain of reference, limited purpose and orientation, limited mode of communication, and "community of participants sharing specialized knowledge and skills" make the speaker understand that with interlanguage $\mathrm{s} / \mathrm{he}$ is exposed to huge risks [3, 122; 4, 56]. In business, such a communication strategy as approximation may play a bad trick on the consequences. For instance, in English for Law in a situation in which a company may not use its assets (property) one speaks of assets being frozen or seized. There is little difference here to a lay-person but a lawyer and experts of the legal profession. According to the online Collins Dictionary, let us compare: "If a government or other authority seize someone's property, they take it from them, often by force" [19] and "If someone in authority freezes something such as a bank account, fund, or property, they obtain a legal order which states that it cannot be used or sold for a particular period of time" [19]. Legally speaking, rights and obligations of the relevant parties as well as legal consequences depend on the accuracy and language proficiency. Next, it is worth considering the syntactical patterns in language for specific purposes. For instance, in English for Audit and Accounting it is critical to observe the term order in a cluster. In Monomial Variables in English Audit Terminology (2019), "it is reasonably found that the monomial as a term can be contrasted with a mere term in a terminological set expression to point to the understanding of (ir)reversibility of the term setting within a certain terminological set expression" [2, 105]. Similarly, it is with binomials / polynomials, in which case the question of irreversibility is fundamental. An example of evidence can be assurance skills and techniques (not assurance techniques and skills), and it is about the linguistic competence that is highly relevant to negotiate the meaning. To this end, it is arguable that communication strategies may be used "[using the language precisely] as a tool to meet the requirements of a specific task only (a sort of "use-and-forget" attitude)" as Dobao

(C) O. I. Chaika

«International journal of philology» | «Міжнародний філологічний часопис» Vol. 11, № 2, 2020 
(1999) suggests for the interlanguage context by exploring two fundamentally different attitudes towards foreign language learning [6, 41]. At the same time, the other approach of "taking advantage of all possible situations to try to expand one's resources with a view to improving one's overall performance in the use of the language" $[6,41]$ highlights the need in linguistic competence of the speaker, however, hardly solving the problems that may arise with the interlanguage. Referring to interlanguage, we adopt the definition by Tarone (2018) of "the linguistic system of the learner language produced by adults when they attempt meaningful communication using a language they are in the process of learning" $[12,1]$.

Conclusion. To sum up, communication strategies remain a truly important element in instruction / acquisition of foreign languages. No doubt, one would say, communicative and strategic competences are of high value to communication process. This is where communication strategies appear to become a powerful tool for the speaker when (i) $s /$ he attempts meaningful communication in a target language (L2) at every level, i.e. phonology, morphology, syntax, semantics, and pragmatics, and (ii) interlanguage as a system does not collect unsystematic errors in lexis and grammar but arises as "a separate transitional linguistic system ... of evolving linguistic patterns and rules" [12, 1]. However, with instruction / acquisition of languages for

\section{References}

1. Chaika, O. (2020). Communicative Strategies in English Business Environment. International journal of philology. Kyiv : «MILENIUM». Vol. 11(1). P. 98-104.

2. Chaika, O. (2019). Monomial Variables in English Audit Terminology. International journal of philology. Kyiv : "MILENIUM». Vol. 10 (1). P. 100-108.

3. Chaika, O. (2018). Ukrainian for Law and Portuguese for Law as 'Understudied' Languages For Specific Purposes. Filolohichnyy chasopys, Vol. 1 (11). P. 118127.

4. Chaika, O. (2018). Language for specific purposes: Ukrainian legal terms of specific purposes linguistic competence may not be ignored as the consequences of CS application may turn unrecoverable in a certain professional context. It is yet unclear to precisely see, design and characterise remedial steps for communication strategies in instruction / acquisition of LSP, on the one hand, and on the other, compensatory communication strategies will undoubtedly promote the speaker's communicative competence while time-gaining strategies may help them advance in interaction by gaining time to think to carry on with the message. Avoidance / reduction strategies may cause unbridgeable trouble in the course of professional communication, though, given that every single term or term cluster, pattern when reduced may adversely influence the context in the professional domain of communication.

Obviously, no final conclusions can be drawn at this point. To establish real significance of the findings, it may be relevant to carry out some statistical investigation into the matter, accounting for decent data of quantitative and qualitative figures. What cannot be argued is proficiency level of linguistic competence. It is of critical important for instruction / acquisition of languages for specific purposes and communication strategies may be viewed as techniques, which may be applicable to gain some time for interlanguage stage.

obligation. Mogilev State University after A. Kuleshov, 51-59.

5. Corder, S.P. (1978). Language learner language. In J.C, Richards (eds.) Understanding Second and Foreign Language Learning: Issues and Approaches. Rowley, MA: Newbury House.

6. Dobao, Ana María Fernández. "Communication Strategies In The Interlanguage Of Galician Students Of English: The Influence Of Learner- And TaskRelated Factors." Atlantis, vol. 23, no. 1, 2001, pp. 41-62. JSTOR.

7. Dornyei, Z. (1995). On the teachability of communication strategies. TESOL Quarterly, 29 (1), 55-86. 
8. Dornyei, Z., \& Scott, M. L. (1995). Communication strategies: An empirical analysis with retrospection. In J. S. Turley \& K. Lusby (Eds.), Selected papers from the proceedings of the twenty-first annual symposium of the desert language and linguistics society (pp.154-168). Prova, UT: Brigham Young University.

9. Dornyei, Z., \& Scott, M. L. (1997). Communication strategies in a second language: Definitions and taxonomies. Language Learning, 47 (1), 173-210.

10. Færch, C. and Kasper, G.(1980) Processes and Strategies in Foreign Language Learning and Communication, $73 \mathrm{p}$.

11. Griffiths, Carol (2004). Language Learning Strategies: Theory and Research. School of Foundations Studies AIS St Helens, Auckland, New Zealand. Occasional Paper No. 1 February, $26 \mathrm{p}$.

12. Tarone, E. (2018). Interlanguage. In The Encyclopedia of Applied Linguistics, C.A. Chapelle (Ed.).

doi:10.1002/9781405198431. wbeal0561.pub2
13. Tarone, E. (1981). "Some thoughts on the notion of communication strategy", TESOL Quarterly, 15, 285-295.

14. Poullisse, N. (1989). The influence of task-and proficiency-related factors on the use of communication strategies: A quantitative analysis. Language learning, p. 30.

15. Poulisse, N.; Bongaerts, T. and E. Kellerman (1993). "A theoretical account of lexical communication strategies", R. Schreuder and B. Weltens [in 6].

16. Stern, H. (1983). Fundamental Concepts of Language Teaching. Oxford: Oxford University Press.

17. Váradi, T. (1980). "Strategies of target language learner communication: message adjustment", International Review of Applied Linguistics, 18, 59-72 [in 6].

18. Zhang, Y. (2007). Communication Strategies and Foreign Language Learning. US-China Foreign Language, ISSN15398080, USA. Apr. 2007, Volume 5, No.4 (Serial No.43). Pp. 43-48.

19. https://www.collinsdictionary.com

\section{КОМУНІКАТИВНІ СТРАТЕГІЇ В ОПАНУВАННІ МОВ ДЛЯ ОСОБЛИВИХ ЦІЛЕЙ О. І. Чайка}

Анотація. У статті розглядається набір комунікативних стратегій, які використовуються у навчанні та вивченні фрахових мов, чи мов особливого призначення, зважаючи на фракт того, що фрахова мова однозначно характеризується відмінними рисами від (просто) мови та рідної мови мовия. Приклади англійською мовою з різних галузей бізнесу та культури, наприклад, англійська мова для бізнесу, права, фінансів та аудиту, управління змінами, лідерства тощо, ілюструють варіативність комунікативних стратегій, які використовуються мовиями, але на відміну від навчання іноземним мовам і оволодіння мовою свідчать про вагомість наявності високого рівня мовленнєвих компетенцій. Завданнями статті є: (i) зробити короткий огляд визначення комунікативної стратеаії; (ii) систематизувати комунікативні стратеаії, які можуть використовуватися мовиями для викладу своїх думок та ідей англійською мовою з конкретною метою в англомовному середовищі та (iii) торкнутися проблематики профресійного спілкування на проміжному етапі навчання спілкування в іноземному мовленнєвому середовищі при оволодіванні новими лінгвістичними та стратегічними навичками та компетенціями. Таким чином, у статті подано описану Дорнеєм (1995) пінгвістичну типологію комунікативних стратезій, яка фоккусується радше на кінцевий мовленнєвий продукт, а не на процес, й такий вибір пояснюється тим, що така класифбікація включає найпоширеніші комунікативні стратеаії, опрацьовані у праиях Вараді, Тарон, Ферха та Каспера, Б'ялосток: (a) стратеаії уникнення, або скорочення змісту; (b) компенсаційні стратеаії; та (c) стратегії, націлені на те, щоб виграти час і надати мовцю можливість зібратися з думками.

Ключові слова: комунікативна стратегія, навчання фаховим мовам, мови особливого призначення, вербальні стратееії, невербальні стратегії.

(C) O. I. Chaika

«International journal of philology» | «Міжнародний філологічний часопис» Vol. 11, № 2, 2020 